Article

\title{
Attraction of Adults of Cyclocephala lunulata and Cyclocephala barrerai (Coleoptera: Scarabaeoidea: Melolonthidae) towards Bacteria Volatiles Isolated from Their Genital Chambers
}

\author{
Abraham Sanchez-Cruz ${ }^{1}$, Norma Robledo ${ }^{1, *} \mathbb{0}$, María Rosete-Enríquez ${ }^{2}$ \\ and Angel A. Romero-López ${ }^{3, *}$ \\ 1 Laboratorio de Ecología Química de Insectos, Centro de Desarrollo de Productos Bióticos, \\ Instituto Politécnico Nacional. Carretera Yautepec-Jojutla, Km. 6, calle CEPROBI No. 8, Col. San Isidro, \\ Yautepec, Morelos C.P. 62731, Mexico; asanchezc1700@alumno.ipn.mx \\ 2 Laboratorio de Macromoléculas, Facultad de Ciencias Biológicas, Benemérita Universidad \\ Autónoma de Puebla, Boulevard Capitán Carlos Camacho Espíritu, Edificio 112-A, Ciudad Universitaria, \\ Col. Jardines de San Manuel, Puebla C. P. 72570, Mexico; maria.rosetee@correo.buap.mx \\ 3 Laboratorio de Infoquímicos y Otros compuestos Bióticos, Facultad de Ciencias Biológicas, \\ Benemérita Universidad Autónoma de Puebla, Boulevard Capitán Carlos Camacho Espíritu, Edificio 112-A, \\ Ciudad Universitaria, Col. Jardines de San Manuel, Puebla C. P. 72570, Mexico \\ * Correspondence: nrobledo@ipn.mx (N.R.); alonso.romerolopez@correo.buap.mx (A.A.R.-L.); \\ Tel.: +52-(735)-3942020 (N.R.); +52-(735)-3941896 (N.R.); +52-(222)-2295500 (A.A.R.-L.)
}

Academic Editors: Francisco (Paco) Barona-Gomez and Derek J. McPhee Received: 31 August 2020; Accepted: 24 September 2020; Published: 27 September 2020

\begin{abstract}
In the study of the chemical communication of adults of the Melolonthidae family, bacteria have been observed in the epithelium of the genital chamber; possibly, bacteria are involved in the production of sex attractants in their hosts. Therefore, it is important to identify the volatile organic compounds from bacteria (VOCsB) released by these microorganisms and study the biological activity stimulated by VOBCs in adults of Melolonthidae. In this study, bacteria were isolated from the genital chamber of Cyclocephala lunulata and Cyclocephala barrerai, from which VOCsB were extracted using static headspace solid-phase microextraction (SHS-SPME) and dynamic headspace Super Q solid-phase extraction (DHS-SPE) and analyzed using gas chromatography-mass spectrometry. The effect of VOCsB on the hosts and conspecifics was evaluated utilizing an olfactometer and electroantennography (EAG). Two species of Enterobacteria were isolated from the genital chamber of each female species, and VOCsB derived from sulfur-containing compounds, alcohols, esters, and fatty acids were identified. An attraction response was observed in olfactometry studies, and antennal responses to VOCsB were confirmed in EAG bioassays. With these results, new perspectives on the relationship between these beetles and their bacteria emerge, in addition to establishing a basis for management programs in the future.
\end{abstract}

Keywords: Cyclocephala; microbial natural products discovery; volatile organic compounds from bacteria; attraction; bioassays; EAG

\section{Introduction}

Several genera of the Melolonthidae family as phytophages are pests of various crops [1,2]; among these is the genus Cyclocephala [3], which has been the less-studied of the family. Members of this genus are widely distributed across the Americas [4], and species such as Cyclocephala lunulata and Cyclocephala barrerai are important pests of diverse plant species like strawberry, guava, and ornamental 
pastures $[2,5,6]$. For the monitoring and management of these beetle species, studies have been carried out to take advantage of the substances involved in intraspecific interactions [7-10], focusing on volatile organic compounds involved in attracting a partner for copulation, such as sex pheromones [11,12]. Bacteria have been observed in the reproductive system of females of Melolonthidae, specifically in the accessory glands and the genital chamber-structures associated with sex pheromones production [10-14]. Based on this evidence, it has been suggested that bacteria participate in the production of these chemicals, such as in the case of Morganella morganii found in the accessory glands of female individuals of melolonthid Costelytra zealandica beetles. These microorganisms produce volatile organic compounds from bacteria (VOCsB) such as phenol, which has been reported as a component of the sex pheromone of $C$. zealandica $[15,16]$. The presence of the enterobacteria Klebsiella oxytoca and Klebsiella michiganensis have also been recorded in the genital chamber of Phyllophaga obsoleta, where a similar relationship may occur [17]. These relationships have not been studied in Cyclocephala (Coleoptera: Scarabaeoidea: Melolonthidae) [3].

Bacterial growth conditions, such as culture media, influence VOCsB diversity and abundance, so it is not appropriate to use general culture media to carry out studies of the production of VOCsB. Bacteria must be cultivated in specific culture media [18-20] containing $10 \%$ glucose and sulfur compounds, as the triple-sugar medium iron (TSI) allows the synthesis of a greater diversity of VOCsB [21]. In the extraction of VOCsB, static headspace solid-phase microextraction (SHS-SPME) has been used to capture these compounds; due to the sensitivity and how they adapt to the bacterial culture, the fibers that have been used in various studies are those of polydimethylsiloxane (PDMS), polyacrylate (PA), and/or divinylbenzene (DVB) for VOCsB of Enterobacteriaceae [22-24]. However, SHS-SPME is a destructive test, which limits its use in bioassays, so dynamic headspace Super Q solid-phase extraction (DHS-SPE) $[25,26]$ is an alternative to obtain samples that can be tested in attraction bioassays; the two forms of extraction are followed by VOCsB identification by gas chromatographic mass-spectrometry (GC-MS) [19,24].

VOCsB, emitted by insect bacteria, play an important role in host chemical communication [27-29]. VOCsB identified in these interactions are hydrocarbons, ketones, alcohols, derivatives with nitrogen or sulfur, and terpenes $[19,20]$; these are involved in the chemical communication of various groups of insects [30,31]. In bioassays (olfactometer and flight tunnel), it has been observed that VOCsB may attract a single sex (sex attractant) or males and females (aggregation attractant) [32-40]. Even though the attraction tests have served to know the biological response of insects to VOCsB, the antennal response they have towards VOCsB is unknown; tests such as electroantennography (EAG) are fundamental to link the behavioral response with the stimulation of the olfactory receptors $[38,40,41]$.

Therefore, this study aimed at isolating and identifying bacteria from the genital chamber of female individuals of $C$. lunulata and C. barrerai to capture and identify the VOCsB they emit, in addition to studying the biological activity of these compounds in the insect hosts. This knowledge could contribute to the future management of these pests where VOCsB may be an important element.

\section{Results and Discussion}

\subsection{Bacteria Isolated from the Genital Chamber of Cyclocephala}

Two culturable bacterial strains were isolated from the genital chamber of $C$. lunulata that were identified as the Klebsiella sp. (GenBank accession number MT239565) and M. morganii (GenBank accession number MT239566). Two strains identified as K. oxytoca (GenBank accession number MG652605) and Citrobacter freundii (GenBank accession number MG652606) were isolated from the females of $C$. barrerai; the strains that demonstrated the closest matches with the NCBI database are presented in Table 1.

These bacteria grow in aerobic conditions using an enriched medium Luria Bertani (LB); the colonies are morphologically similar (Table 2) but show differences in the color and reflected light. Regarding individual characteristics, all are Gram-negative bacillus. 
Table 1. Identification of the bacterial strains isolated from the genital chamber of Cyclocephala lunulata and Cyclocephala barrerai by comparing the homologous sequences of the $16 \mathrm{~S}$ rRNA gene.

\begin{tabular}{|c|c|c|c|c|c|c|}
\hline $\begin{array}{l}\text { Melolonthidae } \\
\text { Specie }\end{array}$ & Strain & Closest Matches & Accession no. & Similarity $(\%)$ & Phylogenetic Affiliation & Host/Isolation Source \\
\hline \multirow{5}{*}{ Cyclocephala lunulata } & \multirow{3}{*}{ Klebsiella sp. MT239565 } & Klebsiella spallanzanii strain SPARK1058C2 & MN091365.1 & 100 & Enterobacteriaceae & $\begin{array}{l}\text { Homo sapiens } \\
\text { (urine) }\end{array}$ \\
\hline & & Klebsiella grimontii strain SS141 & СР044527.1 & 100 & Enterobacteriaceae & Coffee cup \\
\hline & & Klebsiella oxytoca strain 4928 STDY7387762 & LR607363.1 & 100 & Enterobacteriaceae & Feces \\
\hline & \multirow{3}{*}{$\begin{array}{c}\text { Morganella } \\
\text { morganii MT239566 }\end{array}$} & Morganella morganii strain FC6853 & MH628232.1 & 100 & Enterobacteriaceae & Homo sapiens (patient) \\
\hline & & $\begin{array}{l}\text { Uncultured organism clone } \\
\text { ELU0075-T355-S-NIPCRAMgANa_000386 }\end{array}$ & HQ774639.1 & 100 & Enterobacteriaceae & $\begin{array}{c}\text { Homo sapiens } \\
\text { (gastrointestinal) }\end{array}$ \\
\hline \multirow{7}{*}{ Cyclocephala barrerai } & & Morganella morganii subsp. morganii strain JY $16 \mathrm{~S}$ & KR094121.1 & 100 & Enterobacteriaceae & $\begin{array}{l}\text { Medical College, } \\
\text { Soochow University }\end{array}$ \\
\hline & \multirow{3}{*}{$\begin{array}{l}\text { Citrobacter freundii } \\
\text { Cyl_Citf01 } \\
\text { MG652605 }\end{array}$} & $\begin{array}{l}\text { Citrobacter freundii } \\
\text { strain FDAARGOS_61 }\end{array}$ & СР026045 & 99 & Enterobacteriaceae & $\begin{array}{l}\text { Homo sapiens } \\
\text { (rectal swab) }\end{array}$ \\
\hline & & $\begin{array}{l}\text { Citrobacter freundii } \\
\text { strain BD }\end{array}$ & СР018810 & 99 & Enterobacteriaceae & Bactrocera dorsalis (gut) \\
\hline & & $\begin{array}{l}\text { Citrobacter sp. } \\
\text { PT2B }\end{array}$ & GU458283 & 99 & Enterobacteriaceae & $\begin{array}{l}\text { Reticulitermes speratus } \\
\text { (gut) }\end{array}$ \\
\hline & \multirow{3}{*}{$\begin{array}{c}\text { Klebsiella oxytoca } \\
\text { Cyl_Kleb02 } \\
\text { MG652606 }\end{array}$} & Uncultured bacterium & JF208909 & 100 & Enterobacteriaceae & $\begin{array}{l}\text { Homo sapiens } \\
\text { (skin) }\end{array}$ \\
\hline & & $\begin{array}{l}\text { Klebsiella oxytoca } \\
\text { strain CAU9419 }\end{array}$ & MF428632 & 99 & Enterobacteriaceae & pickle \\
\hline & & $\begin{array}{l}\text { Klebsiella oxytoca } \\
\text { strain NGB-FR100 }\end{array}$ & LC049195 & 99 & Enterobacteriaceae & $\begin{array}{l}\text { Root nodules of fava } \\
\text { bean }\end{array}$ \\
\hline
\end{tabular}

Table 2. Morphological characteristics of colonial and individual bacteria isolated from the genital chamber of females of Cyclocephala lunulata and Cyclocephala barrerai.

\begin{tabular}{ccccc}
\hline Morphology & \multicolumn{2}{c}{ Cyclocephala lunulata } & \multicolumn{2}{c}{ Cyclocephala barrerai } \\
& Klebsiella sp. & Morganella morganii & Klebsiella oxytoca & Citrobacter freundii \\
\hline Shape & Circular & Circular & Circular & Circular \\
Edges & Rounded & Rounded & Rounded & Rounded \\
Elevation & Convex & Convex & Convex & Convex \\
Surface & Smooth & Smooth & Smooth & Smooth \\
Consistency & Creamy & Creamy & Creamy & Creamy \\
Pigmentation & Beige & Yellow & Beige & Yellow \\
Transmitted light & Translucent & Translucent & Translucent & Translucent \\
Optical property & Iridescent & Brilliant & Iridescent & Brilliant \\
Size (mm) & 1 & 1 & $1-2$ & 1 \\
Individual morphology & bacillus & bacillus & bacillus & bacillus \\
Gram's reaction & Negative & Negative & Negative & Negative \\
\hline
\end{tabular}


This is the first study of the activity of VOCsB in members of Melolonthidae from Mexico in terms of the isolation of bacteria from the genital chamber, identification of VOCsB emitted from it, and the confirmation of biological activity. The isolation and identification of microorganisms in these species of Cyclocephala are the first recorded for this genus and the third report for Melolonthidae [16,17]; thus, this work provides more information on the diversity of microorganisms associated with the reproductive system of these beetles. The bacterial diversity of the genital chamber of C. lunulata and C. barrerai are like each other and to that reported in other insect species $[29,34,42]$. The hypothesis is that bacteria can be acquired through food mainly during the larval state, and upon reaching the genital epithelium, they adapt, as that provides them with the conditions for their survival $[34,36]$. The host does not depend on a sole bacterial species for chemical communication, and thus, in case of losing a member of the bacterial community, the host can replace it [35]. Concerning the VOCsB produced by the genus Klebsiella colonies, the emission of indole is characteristic [43,44]. The genome of K. oxytoca suggests that this microorganism may emit short-chain alcohols [45]; the emission of 3-methyl butane-1-ol in K. oxytoca is the first report with an amino acid-rich culture medium [24].

\subsection{Identification of $V O C s B$}

VOCsB recovered by SHS-SPME (Table 3), the total ion chromatogram representative of the four bacteria, are shown in Figure 1; the peaks are numbered relative to those indicated in Table 3. For both Klebsiella sp. and M. morganii bacterial strains isolated from C. lunulata, they were comprised of similar VOCsB derived from sulfur and large-chain alcohols, in addition to aromatic alcohols and indole, with the only difference that Klebsiella sp. emitted 2-tridecanone and M. morganii emitted 1-undecanol. For the bacterial strains isolated from C. barrerai, short-chain alcohol, aromatic alcohol, indole, and two fatty acid esters were recorded in K. oxytoca; this was the species that emitted the least number of VOCsB, in contrast to Ci. Freundii, where thirteen compounds were identified - three derived from sulfur, two large-chain alcohols, two aromatic alcohols, a carboxylic acid, and three fatty acid esters. Aromatic and sulfur-derived alcohols were identified in the compounds captured by DHS-SPE from C. lunulata, Klebsiella sp., and C. barrerai; however, the K. oxytoca strain was distinct, since only 2-phenyl ethanol was identified. 
Table 3. VOCsB from the Klebsiella sp. captured by SHS-SPME and DHS-SPE.

\begin{tabular}{|c|c|c|c|c|c|c|}
\hline Specie Bacteria & Pk No. & Extraction Technique & VOCsB & KRI & Ref. KRI & Characteristic EI ions \\
\hline \multirow{7}{*}{ Klebsiella sp. } & 1 & SHS-SPME & (methyl disulfanyl) methane & 691 & $735[46]$ & $45,61,69,79,83,91,94(\mathrm{M}+)$ \\
\hline & 2 & SHS-SPME & (methyl trisulfanyl) methane & 966 & $961[46]$ & $64,79,83,111,113,126(\mathrm{M}+)$ \\
\hline & 3 & SHS-SPME & phenol & 977 & $980[47]$ & $40,55,66,74,94(\mathrm{M}+)$ \\
\hline & 4 & SHS-SPME & 2-phenylethanol & 1087 & $1078[48]$ & $51,65,77,91,92,122(\mathrm{M}+)$ \\
\hline & 5 & SHS-SPME & decan-1-ol & 1234 & $1256[49]$ & $43,70,83,97,112,140,158(\mathrm{M}+)$ \\
\hline & 6 & SHS-SPME & indole & 1251 & $1288[50]$ & $40,58,63,74,90,102,117(\mathrm{M}+)$ \\
\hline & 7 & SHS-SPME & tridecan-2-one & 1475 & $1474[51]$ & $43,58,71,85,96,140,198(\mathrm{M}+)$ \\
\hline \multirow{8}{*}{ Morganella morganii } & 1 & SHS-SPME & (methyl disulfanyl) methane & 691 & $735[46]$ & $45,61,69,79,83,91,94(\mathrm{M}+)$ \\
\hline & 2 & SHS-SPME/DHS-SPE & (methyl trisulfanyl) methane & 966 & $961[46]$ & $64,79,83,111,113,126(\mathrm{M}+)$ \\
\hline & 3 & SHS-SPME/DHS-SPE & phenol & 977 & $980[47]$ & $40,55,66,74,94(\mathrm{M}+)$ \\
\hline & 4 & SHS-SPME/DHS-SPE & 2-phenylethanol & 1087 & $1078[48]$ & $51,65,77,91,92,122(\mathrm{M}+)$ \\
\hline & 5 & SHS-SPME & decan-1-ol & 1234 & 1256 [49] & $43,70,83,97,112,140,158(\mathrm{M}+)$ \\
\hline & 6 & SHS-SPME & indole & 1251 & $1288[50]$ & $40,58,63,74,90,102,117(\mathrm{M}+)$ \\
\hline & 7 & SHS-SPME & undecan-1-ol & 1282 & $1372[51]$ & $55,69,83,97,111,154,172(\mathrm{M}+)$ \\
\hline & 1 & SHS-SPME & 3-methylbutan-1-ol & 688 & $734[50]$ & $42,55,57,70,87,88(\mathrm{M}+)$ \\
\hline \multirow{5}{*}{ Klebsiella oxytoca } & 2 & SHS-SPME/DHS-SPE & 2-phenylethanol & 1087 & $1078[48]$ & $51,65,77,91,92,122(\mathrm{M}+)$ \\
\hline & 3 & SHS-SPME & ethyl octanoate & 1179 & $1192[52]$ & $57,88,127,172(\mathrm{M}+)$ \\
\hline & 4 & SHS-SPME & decan-1-ol & 1234 & 1256 [49] & $43,70,83,97,112,140,158(\mathrm{M}+)$ \\
\hline & 5 & SHS-SPME & indole & 1251 & $1288[50]$ & $40,58,63,74,90,102,117(\mathrm{M}+)$ \\
\hline & 6 & SHS-SPME & dodecan-1-ol & 1461 & 1473 [53] & $69,83,97,111,140,168,186(\mathrm{M}+)$ \\
\hline \multirow{9}{*}{ Citrobacter freundii } & 7 & SHS-SPME & tridecan-2-one & 1475 & $1474[51]$ & $58,71,140,169,183,198(\mathrm{M}+)$ \\
\hline & 1 & SHS-SPME & (methyldisulfanyl) methane & 691 & $735[46]$ & $45,61,69,79,83,91,94(\mathrm{M}+)$ \\
\hline & 2 & SHS-SPME/DHS-SPE & (methyltrisulfanyl) methane & 966 & $961[46]$ & $64,79,83,111,113,126(\mathrm{M}+)$ \\
\hline & 3 & SHS-SPME/DHS-SPE & phenol & 977 & $980[47]$ & $40,55,66,74,94(\mathrm{M}+)$ \\
\hline & 4 & SHS-SPME/DHS-SPE & 2-phenylethanol & 1087 & $1078[48]$ & $51,65,77,91,92,122(\mathrm{M}+)$ \\
\hline & 5 & SHS-SPME & ethyl octanoate & 1179 & $1192[52]$ & $57,88,127,143,157,172(\mathrm{M}+)$ \\
\hline & 6 & SHS-SPME/DHS-SPE & (methyltetrasulfanyl) methane & 1204 & $1210[54]$ & $45,64,79,94,111,145,158(\mathrm{M}+)$ \\
\hline & 7 & SHS-SPME & decan-1-ol & 1234 & $1256[49]$ & $43,70,83,97,112,140,158(\mathrm{M}+)$ \\
\hline & 8 & SHS-SPME & undecan-1-ol & 1282 & $1372[51]$ & $55,69,83,97,111,154,172(\mathrm{M}+)$ \\
\hline
\end{tabular}

Pk No (peak number), headspace-solid phase microextraction (SHS-SPME), dynamic headspace Super Q solid-phase extraction (DHS-SPE), volatile organic compounds from bacteria (VOCsB), and Kovats Retention Index (KRI), Electron Ionization (EI). 

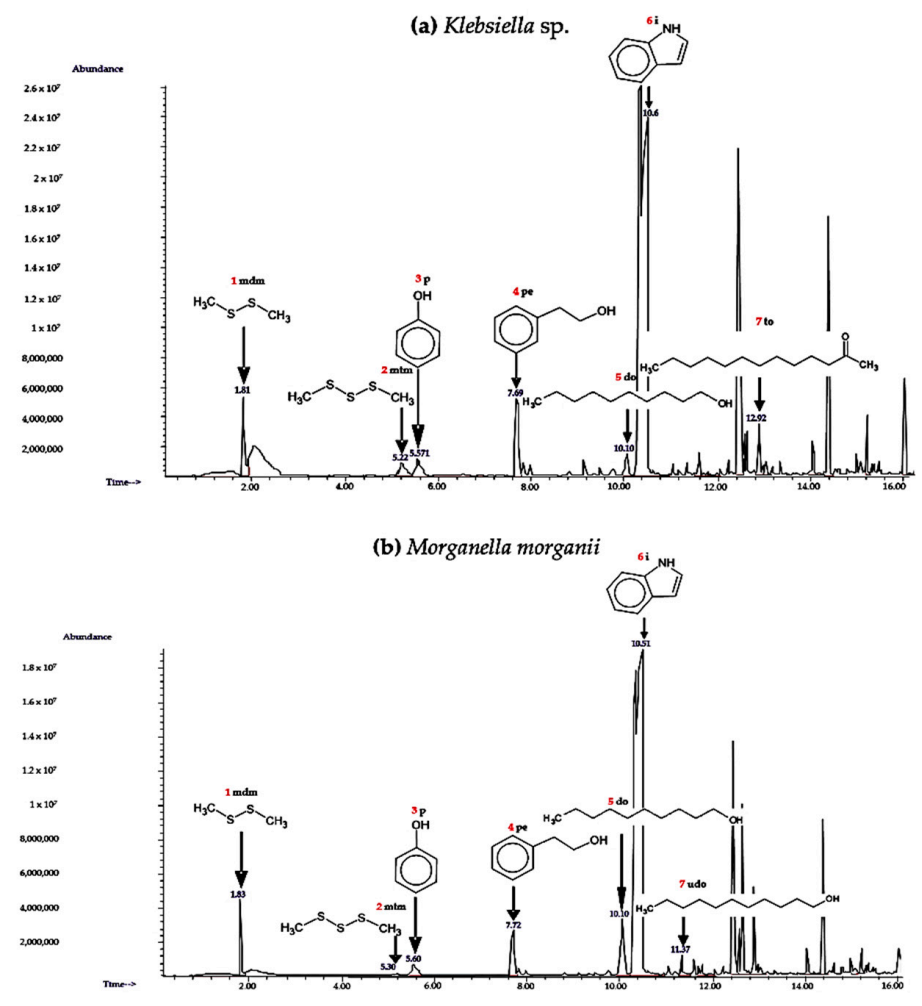

(c) Klebsiella oxytoca

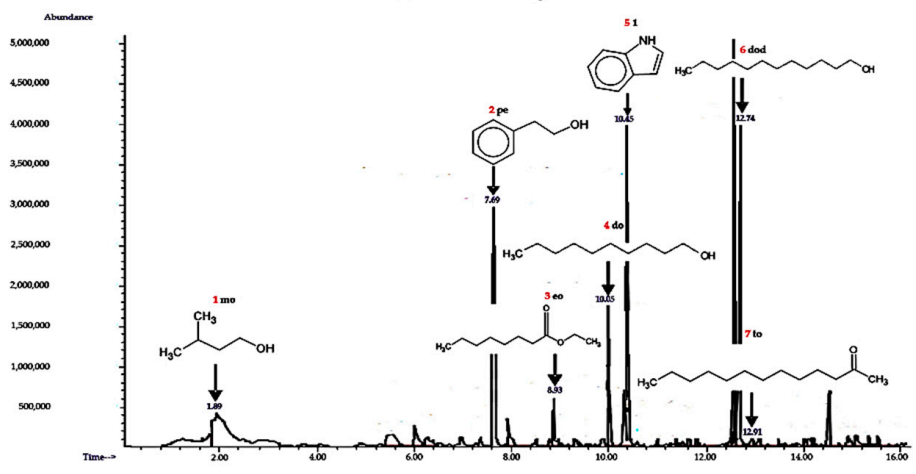

(d) Citrobacter freundii

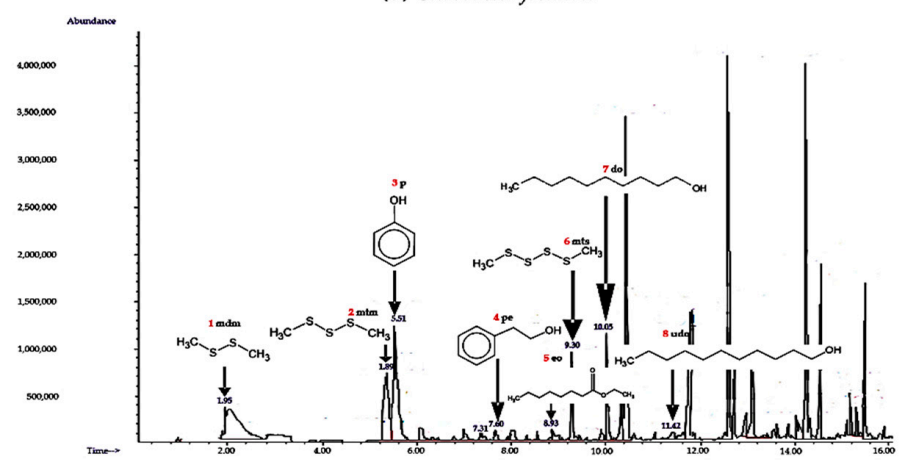

Figure 1. Representative total ion chromatogram and chemical structure of the volatile organic compounds from bacteria (VOCsB) from bacteria isolated in the genital chamber of Cyclocephala lunulata $(\mathbf{a}, \mathbf{b})$ and Cyclocephala barrerai $(\mathbf{c}, \mathbf{d})$. Red color: peak number and blue: retention time (minutes). (Methyl disulfanyl) methane (mdm), (methyl trisulfanyl) methane (mtm), phenol (p), 2-phenylethanol (pe), decan-1-ol (do), indole (i), tridecan-2-one (to), undecan-1-ol (vdo), 3-methylbutan-1-ol (mo), dodecan-1-ol (dod), and (methyltetrasulfanyl) methane (mts). 
The genome of K. oxytoca suggests that this microorganism may emit short-chain alcohols [45]. The emission of aromatic alcohols is common in bacteria of the family Enterobacteriaceae [18] to which Cyclocephala bacteria belong, as well as the bacteria isolated from other Melolonthidae previously studied [16,17]. The emission of 3-methyl butane-1-ol in K. oxytoca is the first report with an amino acid-rich culture medium [24]. These aromatic alcohols, in general, are very attractive to insects in behavioral bioassays [42,55]. There is a relationship between the species that can metabolize compounds derived from sulfur and phenol; VOCsB that contain sulfur are related to the bacterial metabolism of phenol [21], such as in the case of K. oxytoca that did not produce phenol nor sulfur derivatives. The production of phenol is related to the attraction of conspecifics to the insects harboring the emitting bacteria; this compound is present in the pheromones of several Melolonthidae [10,41,56-58], including Cyclocephala sp. [59].

\subsection{Insect Attraction to $\mathrm{VOCsB}$}

In C. lunulata (Figure 2a), 90\% of males and 73.6\% of females selected the VOCsB emitted by M. morganii rather than those from the control; both results were statistically significant: $\chi^{2}=6.40$, $p=0.01$, degrees of freedom $(\mathrm{df})=9, \mathrm{n}=10$, and $\chi^{2}=4.36, p=0.03, \mathrm{df}=18, \mathrm{n}=19$, respectively. This demonstrates that the VOCsB from $M$. morganii attract both sexes. The results regarding attraction to the VOCsB obtained from Klebsiella sp. were inconclusive, and therefore, studies are still in progress. In C. barrerai (Figure $2 \mathrm{~b}$ ), $77.7 \%$ of males significantly preferred the compounds emitted by Ci. freundii rather than those of the control $\left(\chi^{2}=5.56, p=0.01, \mathrm{df}=17, \mathrm{n}=18\right)$. In regard to the VOCsB emitted by $K$. oxytoca, $61 \%$ of male individuals preferred these over the control; however, this result was not statistically significant $\left(\chi^{2}=0.89, p=0.34, \mathrm{df}=17, \mathrm{n}=18\right)$. There were no attraction tests for females of this species due to the low number of female insects captured.

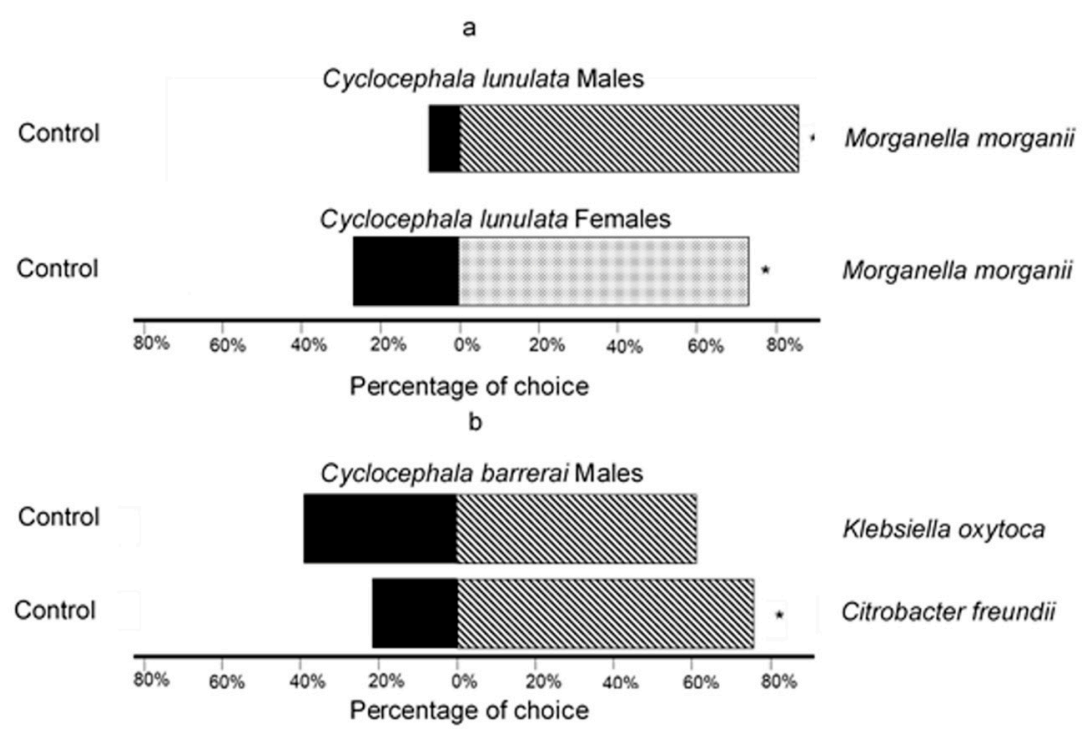

Figure 2. Attraction of Cyclocephala lunulata and Cyclocephala barrerai towards VOCsB from the bacteria resident of the genital chamber of females. Asterisks indicate significant differences in $\chi^{2}$ test and $p>0.05$.

(a) Males $(\mathrm{n}=10)$ and females $(\mathrm{n}=19)$ of C. lunulata attracted to VOCsB from Morganella morganii;

(b) Males of C. barrerai $(\mathrm{n}=18)$ attracted to VOCsB from Klebsiella oxytoca and Citrobacter freundii.

In tests on the attraction of C. lunulata to bacteria from C. barrerai (Figure 3), 77.7\% of males selected the VOCsB emitted by $C i$. freundii rather than those from the control $\left(\chi^{2}=5.56, p=0.01\right.$, $\mathrm{df}=17, \mathrm{n}=18), 61 \%$ of males selected the VOCsB emitted by $K$. oxytoca rather than those from the control $\left(\chi^{2}=0.89, p=0.34, \mathrm{df}=17, \mathrm{n}=18\right)$. For the females of $C$. lunulata, $77.7 \%$ selected the VOCsB emitted by $C i$. freundii rather than those from the control $\left(\chi^{2}=5.56, p=0.01, \mathrm{df}=17, \mathrm{n}=18\right)$, and $73 \%$ of 
females selected the VOCsB emitted by K. oxytoca; however, this result was not statistically significant $\left(\chi^{2}=3.56, p=0.59, \mathrm{df}=17, \mathrm{n}=18\right)$.

Although is not possible the compounds are part of the pheromones, our results confirm that VOCsB act as attractants [7], because adults of C. lunulata responded to VOCsB obtained from the bacteria isolated from C. barrerai; in particular, to those that had 2-phenyl ethanol, phenol, and sulfur derivatives. In this work, it was observed that C. lunulata and C. barrerai display attraction behaviors to VOCsB in the bioassays, walking against the wind towards the source of emission [60,61].

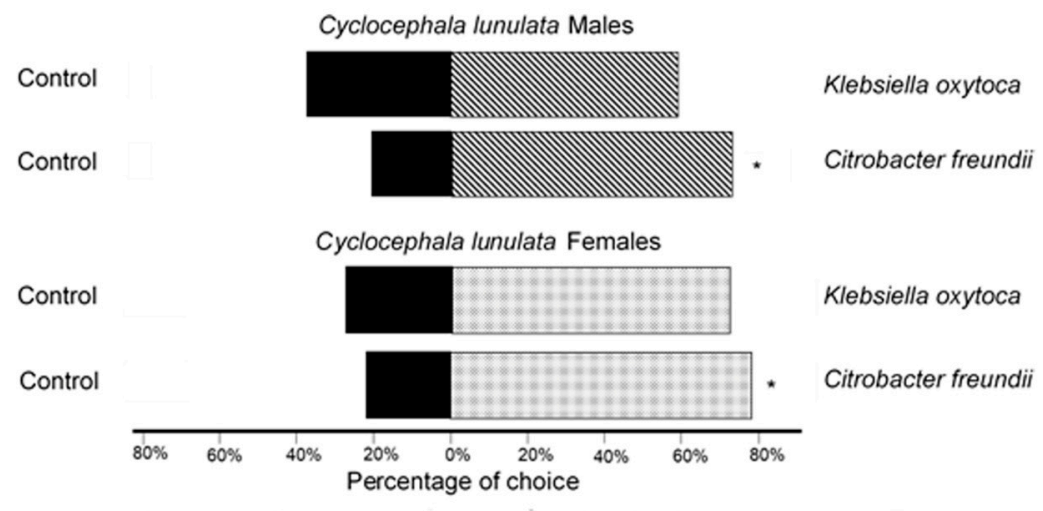

Figure 3. Attraction of females $(n=18)$ and males $(n=18)$ of Cyclocephala lunulata towards the VOCsB of the bacteria resident of the genital chamber of females of Cyclocephala barrerai. The asterisk indicates significant differences in $\chi^{2}$ test, and $p>0.05$ ).

\subsection{Test of $E A G$}

In the EAG bioassays, the antennae of female individuals of C. lunulata to the VOCsB of M. morganii (Figure 4) presented a statistically significant greater response to VOCsB than to the control $(t=2.80$, $\mathrm{n}=11, p=0.01)$.

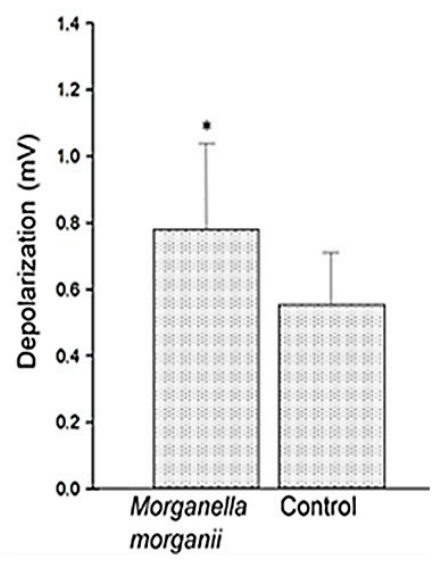

Figure 4. Antennal depolarization of Cyclocephala lunulata at VOCsB of Morganella morganii. The asterisk indicates significant differences in the paired $t$-test $(\mathrm{n}=11, p>0.05)$.

From the antennal response to VOCsB of Ci. freundii and K. oxytoca (Figure 5), the antennae of male C. barrerai presented a statistically significant greater response to VOCsB than to the control $(\mathrm{F}=7.19$, $\mathrm{df}=9, p<0.01)$. In $C$. lunulata, the females presented a statistically significant greater response to VOCsB than to the control $(\mathrm{F}=5.272, \mathrm{df}=11, p=0.01)$ and males $(\mathrm{F}=4.022, \mathrm{df}=10, p=0.03)$. 
In view of the above, the EAG tests revealed that those compounds produced antennal responses where phenol showed the greatest effects. EAG tests are important to ensure that the insect recognizes the substance to which it is exposed [62]. The attraction of beetles to VOCsB has been widely studied; however, the study of the antennal response has not, whereas EAG studies have been carried out for pheromones, allowing to relate attraction and recognition in the insect [7]. In this study, it was observed that VOCsB caused antennal depolarization, particularly those containing aromatic alcohols, such as phenol and 2-phenylethanol.
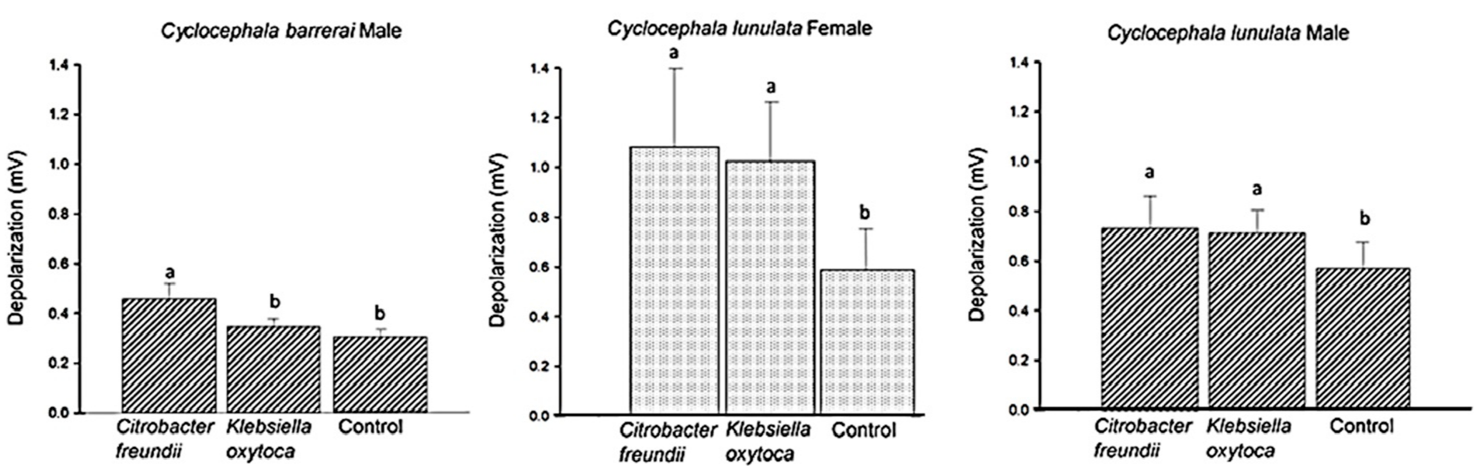

Figure 5. Antennal depolarization of Cyclocephala barrerai and Cyclocephala lunulata at VOCsB of Citrobacter freundii and Klebsiella oxytoca. Different letters indicate statistically different values by ANOVA Repeat Measures (RM) (Fisher Least significant difference (LSD), $\mathrm{n}=12, p>0.05$ ).

The attraction of both male and female individuals of C. lunulata towards several of the VOCsB indicates that these are aggregation attractants [62,63]. Aggregation has been cited for species from Dynastinae; although the production of these chemical substances has been primarily associated with males [37,39,64-69], there are reports of female beetles emitting this type of pheromone as well $[70,71]$. In this study, the females of Cyclocephala produced the compounds, possibly with the assistance of bacteria associated with their genital chamber, and this coincides with other studies reporting that VOCsB act as aggregation attractants for their insect hosts [35,36]. In other studies, the VOCsB of Bactrocera zonata Saunders attract a greater number of females [18], and the VOCsB from the intestinal microbiota of Dendroctonus ponderosae Hopkins provoke aggregation for the mass invasion of trees [72].

The emission of alcohols by bacteria from the genital chamber of C. lunulata could also serve a defensive role against pathogenic microorganisms, in addition to their function in insect chemical communication. Alcohol derivatives such as phenol and, particularly, long-chain alcohols are usually produced by members of Enterobacteriaceae [25], and they inhibit the growth and development of Gram-positive bacteria, fungi [2,73], and the most representative species of insect pathogens [74]. This could explain why, until now, all bacteria isolated from the female reproductive apparatus of Melolonthidae beetles belonged to Enterobacteriaceae. For instance, the intestinal bacteria of Schistocerca gregaria [35] act primarily as a form of defense and participate in the synthesis of food and secondarily function in the chemical communication of the host. Therefore, bacteria from different species are metabolically similar and emit similar compounds [18].

\section{Materials and Methods}

\subsection{Insects}

The collection of adult specimens was conducted during the periods April-June 2017, April-June 2018, and March-July 2019. The C. lunulata adults were collected in green spaces within the municipalities of Yautepec $\left(18^{\circ} 53^{\prime} 10.5^{\prime \prime} \mathrm{N} 99^{\circ} 04^{\prime} 17.9^{\prime \prime} \mathrm{W}\right.$ and Cuautla, Morelos $\left(18^{\circ} 49^{\prime} 51.5^{\prime \prime} \mathrm{N}\right.$ $\left.98^{\circ} 56^{\prime} 40.1^{\prime \prime} \mathrm{W}\right)$, Mexico between 23:00 and 24:00 h, and the adults of $C$. barrerai were collected in the green 
spaces of the "Benemérita Universidad Autónoma de Puebla" (BUAP) (1900'17.1" N 98 12'08.5" W)

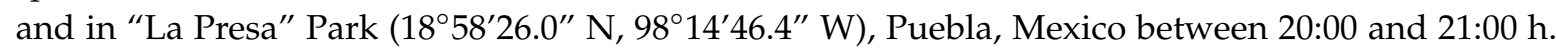
Insects were identified using the keys created by Morón [75]. Each species was separated according to sex, and groups of ten individuals were placed in 1-L bottles with $50 \%$ soil and organic material; every third day, the beetles were fed on Psidium sp. fruit, and the soil was moistened with water. The beetles were left for at least five days without copulation for the subsequent experiments.

\subsection{Microorganisms of the Female Reproductive System}

Based on the technique proposed by Rosete-Enríquez and Romero-López [17], bacteria were extracted from the genital chamber of 10 females of C. lunulata and C. barrerai. The colony-forming units of each bacterial strain were cultivated to describe their colonial morphology and identifying bacterial morphology using Gram staining.

Genomic DNA was extracted and purified according to the Wizard ${ }^{\circledR}$ Genomic DNA Purification Kit (Promega, Madison, WI, USA). The amplification of two segments of the 16S rRNA gene was performed by a polymerase chain reaction (PCR) based on the protocol proposed by Rosete-Enríquez and Romero-López [17]. Briefly, two reactions carried out using 10 ng of genomic DNA, 200- $\mu$ M deoxynucleotide solution mix (dNTPs), $1 \mu \mathrm{M}$ of each pair of upper and lower primers, 2 or 1.5-mM $\mathrm{MgCl}_{2}, 1.25$ units of PlatimunTM Taq DNA polymerase, 1X PCR buffer (Invitrogen, Carlsbad, CA, USA), and DNase free water to make $20 \mu \mathrm{L}$. The sequence of primers for the first reaction was 8F 5' AGAGTTTGATCCTGGCTCAG 3' and 907R 5' CCGTCAATTCM TTTRAGTTT 3'. The second reaction was conducted with primers 533F 5' GTGCCAGCAGCCGCGGTAA 3' and 1496R 5' GGTTAC.CTTGTTACGACTT 3'. Amplifications were performed in a Techne 412 thermocycler (Bibby Scientific, Staffordshire, UK) with the following cycling program: initial denaturation for $5 \mathrm{~min}$ at $94{ }^{\circ} \mathrm{C}, 35$ or 30 cycles for $45 \mathrm{~s}$ at $94^{\circ} \mathrm{C}, 55^{\circ} \mathrm{C}$ or $56^{\circ} \mathrm{C}$ for $1 \mathrm{~min}, 72{ }^{\circ} \mathrm{C}$ for $1.5 \mathrm{~min}$, and a final extension at $72{ }^{\circ} \mathrm{C}$ for $10 \mathrm{~min}$. The molecular weight of the amplicons was determined by comparison with the migration of the 100-bp molecular marker. The PCR amplicons were purified from band cutting following the instructions of the QIAquick Gel Extraction kit (Qiagen). Once the amplicon concentration was verified, sequencing was performed using the Sanger method in the sequencing unit of the Institute of Biology of BUAP, Mexico. The sequences were edited and assembled with the free distribution software Bioedit 7.0 [76]. Genus and species identification were carried out using BLAST in the database of the National Center for Biotechnology Information (NCBI, https://blast.ncbi.nlm.nih.gov/Blast.cgi), comparing the sequence obtained from the rRNA 16s gene with reference sequences recorded in the database. The analysis of the sequences was performed by CLUSTALW method [77] alignment, followed by a calculation of genetic pairwise distances using the neighbor-joining method [78]. Estimation of variance was performed by Bootstrap with 10,000 resamples, with a model of nucleotide substitution using the Kimura 2 parameters analysis [79] and gamma distribution pattern. The matrix of the genetic distances was completed using the freely distributed software MEGA 7 (1.0 version, State College, PA, USA) [80].

\subsection{Extraction and Identification of $V O C s B$}

The bacterial strains were cultivated in round, glass flasks containing $50 \mathrm{~mL}$ of triple-sugar iron (TSI) sterile culture. The bottles were pressure-sealed using an aluminum top with a silicon septa in its center. The system was incubated $8 \mathrm{~h}$ at $30^{\circ} \mathrm{C}$ :

1. VOCsB were captured by SHS-SPME, inserting a 65- $\mu \mathrm{M}$ PDMS/DVB fiber (Supelco, Inc., Bellefonte, PA, USA) into the bottle and maintaining the system for $16 \mathrm{~h}$ at $30^{\circ} \mathrm{C}$. After removing the fiber, the sample was analyzed by GC-MS. Ten repetitions were carried out for each bacterial strain in TSI; the control was a sterile TSI medium without bacteria.

2. The capture of VOCsB by DHS-SPE was performed under the aforementioned conditions for bacterial growth in the TSI medium; cultures were incubated for a period of $8 \mathrm{~h}$ at $30{ }^{\circ} \mathrm{C}$. Pasteur pipette with $125 \mathrm{mg}$ of Super Q 80/100 (Alltech Assoc, Inc., Deerfield, IL, USA) was 
connected to the upper part of the flask through the silicone septa. Once the Pasteur pipette was inserted, the experiment was maintained for $16 \mathrm{~h}$ at $30^{\circ} \mathrm{C}$.

The end of the incubation period, the culture system was removed, and the end of the Pasteur pipette was connected to a Welch USA double-flow pump with a constant suction flow of $500 \mathrm{~mL} / \mathrm{min}$ for $1 \mathrm{~h}$ at $27^{\circ} \mathrm{C}$. The compounds were diluted in $2 \mathrm{~mL}$ of hexane (HPLC, JT Barker®, Chemical company, NJ, USA) and reconcentrated to $200 \mu \mathrm{L}$ with a nitrogen current. An GC-MS (7890A-5975C, Agilent, Santa Clara, CA, USA), with an HP-5MS column (19091S-433, Agilent, Santa Clara, NJ, USA) (30 m, $0.250-\mu \mathrm{m}$ internal diameter, and $0.25-\mu \mathrm{m}$ thickness) was used for the identification of the VOCsB captured by both extraction methods. Aliquots $(2 \mu \mathrm{L})$ of the extracts were analyzed by GC-MS; oven start temperature of $50^{\circ} \mathrm{C}$ for $2 \mathrm{~min}$, increased to $220^{\circ} \mathrm{C}$ by $8{ }^{\circ} \mathrm{C} / \mathrm{min}$, and maintained for $2 \mathrm{~min}$; the injection port functioned in the splitless $1: 10$ mode at a temperature of $250{ }^{\circ} \mathrm{C}$ [24]; the flow was $2 \mathrm{~mL} / \mathrm{min}$ of hydrogen as a carrier gas. The mass spectrometer worked with electronic ionization (70 EV) in SCAN mode and a mass range of 35 to 550 Atomic Mass Unit AMU. Only the compounds that were present in at least $90 \%$ of the test samples and absent in the control were identified by their retention times, Kovats Retention Index [81], and through comparison of their mass spectra with the spectral library NIST/EPA/NIH (Software Version 2.0, Gaithersburg, MD, USA). The chemical structure is made with the software ADC/ChemSketch Freeware 2020, Canada.

\subsection{Bioassays}

\subsubsection{Olfactometer}

A glass Y-tube olfactometer consisting of a central 14-cm-long tube and two 13-cm-long arms with an internal diameter of $1.5 \mathrm{~cm}$ was used. Each arm was connected to a 6.5-cm-long and 2.5-cm-internal diameter glass chamber, where the stimulants were placed. For the stimulus impulse, a wind flow of $500 \mathrm{~mL} / \mathrm{min}$ provided by a double-flow pump (2522B-01, WELCH, Niles, IL, USA) was used, regulated by a flowmeter (Cole-Palmer, Chicago, IL, USA), at $1 \mathrm{~L} / \mathrm{min}$ in the central tube. The bioassays were conducted between 20:30 h-21:30 h for C. barrerai and 23:00 h-1:00 h for C. lunulata under controlled conditions of $27 \pm 1^{\circ} \mathrm{C}, 50 \%$ relative humidity, and illuminated by a 15-W red light (Philips, Shenzhen, China). The bacterial extracts were used as stimuli and the sterile medium as the control. To the stimuli, $2 \mu \mathrm{L}$ were added on a piece of $5 \times 2-\mathrm{mm}$ filter paper (Whatman No. $1^{\circledR} 2 \mathrm{~V}, \mathrm{Merck} \mathrm{KGaA}$, Darmstadt, Germany), which were placed inside each end of the olfactometer and left for $20 \mathrm{~s}$ to allow the volatilization of the stimulus. The test was conducted with female and male beetles that did not copulate during the previous 5-7 days. The behavior of the adults was filmed using a camera (WB800F, Samsung, Daegu, South Korea), and the response of everyone to each stimulus was recorded. A positive response was considered as an individual reaching at least halfway along the glass arm and remaining at the side that was selected for over $30 \mathrm{~s}$ [60]. There was a pause of 5 min between each test during which a flow of air cleaned the system to ensure any volatile remnants were removed. The arm where the stimuli were placed was alternated randomly, and only one sex was analyzed per day. Before each bioassay, the olfactometers were washed and rinsed with hexane and dried at $100{ }^{\circ} \mathrm{C}$. The data were analyzed using a $\chi^{2}$ test and presented as the total percentage of repetitions. The video recordings were revised, and photos were obtained that were used to chart the behavior patterns presented by the individual beetles before, and then, they selected a stimulus.

\subsubsection{Electroantennography}

EAG responses were conducted using EAG equipment (Syntech, Kirchzarten, Germany). A recently dissected antenna of each adult was mounted between 2 silver electrodes using conductor gel (Sigma gel, SYNTECH, Spectra 360, Parker, Orange, NJ, USA). The signal generated by the antenna was transmitted to an IDAC-2 amplifier, recorded, and analyzed with software (SYNTECH EAG PRO 2.0, 2005, SYNTECH, Hilversum, The Netherlands). A constant flow of humidified pure air $(0.5 \mathrm{~L} / \mathrm{min})$ provided by a pump (stimulus controller SC-55) was directed onto the antenna through 
a glass tube (diameter $10 \mathrm{~mm}$ ). To present a stimulus, a pipette tip containing the stimulus of $2 \mu \mathrm{L}$ of VOCsB extract headspace was placed on filter paper $(5 \times 2 \mathrm{~mm}$, Whatman No. 1) was inserted through a side hole located at the midpoint of the glass tube. The outlet of the glass tube was positioned approximately $2 \mathrm{~cm}$ from the antenna. Humidified pure air flowed at $0.5 \mathrm{~L} / \mathrm{min}$ through the pipette during stimulation. For stimulus application, $2 \mu \mathrm{L}$ of stimuli were placed on filter paper $(5 \times 2 \mathrm{~mm}$, Whatman No. 1). A dilution of standard eucalyptol $(50 \mu \mathrm{L} / \mathrm{mL})$ was used as an entrance and exit stimulus for C. lunulata and linalool $(50 \mu \mathrm{L} / \mathrm{mL})$ for $C$. barrerai to verify the basal state of the antenna. All the standards were provided by Sigma Aldrich ${ }^{\circledR}$ (Toluca, Mexico). The stimuli were the VOCsB extracts and the control (extract of TSI); they were randomly placed in the arms of the olfactometer. In each experiment, the solvent was left to evaporate for $20 \mathrm{~s}$, and the time interval between each stimulus was $60 \mathrm{~s}$. In these bioassays, the antennal depolarization response to the solvent was subtracted from the response to the stimuli before analysis. Once obtained, the antennal responses were analyzed with the software; the data were normalized, calculating the EAG values as a relative percentage to the entrance and exit stimuli to eliminate the error caused by a loss of sensibility in the antenna.

\subsection{Statistical Analysis}

Olfactometry bioassays behavior was analyzed using $\chi^{2}$. EAG data were log-transformed and analyzed by a paired $t$-test and ANOVA Repeat Measures (RM), SigmaPlot 12.0, SYSTAT Software, Chicago, IL, USA.

\section{Conclusions}

Female C. lunulata and C. barrerai possess bacteria in their genital chamber, C. lunulata possesses the bacteria M. morganii and Klebsiella sp., and female C. barrerai possess the bacteria K. oxytoca and Ci. freundii. Klebsiella sp. and M. morganii emit VOCsB derived from sulfur; alcohols; and aromatic alcohols such as methyltrisulfanyl methane, decan-1-ol, and phenol. VOCsB of M. morganii cause attraction responses and antenatal responses in females and males of $C$. lunulata, functioning as aggregation attractants. Klebsiella oxytoca emits VOCsB such as aromatic compounds and aliphatic and aromatic alcohols, including decan-1-ol and 2-phenyletanol. In the bioassays, no significant differences were observed in the attraction responses of males of $C$. barrerai and males and females of C. lunulata to K. oxytoca VOCsB, although these compounds caused an antennal response in these beetles. Finally, Ci. freundii emitted a large number of sulfur-derived compounds; alcohols; and aromatic alcohols such as (methyldisulfanyl) methane, (methyltrisulfanyl) methane decan-1-ol, and phenol. These VOCsB cause the attraction of male C. barrerai and male and female C. lunulata, functioning as aggregation attractants. As VOCsB function as aggregation attractants, they could be used in mass trapping for the management of $C$. lunulata. This study is novel in terms of the identification of VOCsB and their biological activity in their hosts.

Author Contributions: M.R.-E., A.A.R.-L., and. A.S.-C. conceived the idea of the experiment; N.R. got funding; N.R., A.A.R.-L., and M.R.-E. supervised the experimental and analytical work carried out by A.S.-C.; N.R., A.A.R.-L., and A.S.-C. contributed to the discussion of the results; and N.R., A.A.R.-L., M.R.-E., and. A.S.-C. wrote and revised the manuscript. All authors have read and agreed to the published version of the manuscript.

Funding: N.R. is an EDI: IPN fellow. A.S.-C. was supported by a scholarship from the "Consejo Nacional de Ciencia y Tecnología de México" (CONACyT). We thank the "Secretaría de Investigación y Posgrado del Instituto Politécnico Nacional" for funding (SIP 20181451).

Acknowledgments: We thank Bravo-Luna L. for assistance in insect collection and Rivas L. for technical support.

Conflicts of Interest: The authors declare no conflicts of interest. The funders had no role in the design of the study; in the collection, analyses, or interpretation of data; in the writing of the manuscript; or in the decision to publish the results. 


\section{References}

1. Jackson, T.A.; Klein, M.G. Scarabs as pests: A continuing problem. Coleopt. Bull. 2006, 60, 102-119. [CrossRef]

2. Morón, M.Á.; Nogueira, G.; Rojas-Gómez, C.V.; Arce-Pérez, R. Biodiversidad de Melolonthidae (Coleoptera) en México. Rev. Mex. Biodivers. 2014, 85, 298-302. [CrossRef]

3. Cherman, M.A.; Grossi, P.C. A crop pest species of Cyclocephala Dejean (Coleoptera: Melolonthidae: Dynastinae) misidentified for over twenty years in Southern Brazil. Bragantia 2020, 79, 372-376. [CrossRef]

4. Ratcliffe, B. The Dynastinae scarab beetles of Costa Rica and Panama (Coleoptera: Scarabaeidae: Dynastinae). Bull. Univ. Neb. State Mus. 2003, 16, 506-527.

5. Abarca, G.; Quesada, M. Especies del complejo de jobotos (Phyllophaga spp., Anomala spp. y Cyclocephala spp.) asociadas a cultivos en el Valle Central y Pacífico Seco de Costa Rica. Agron. Mesoam. 1997, 8, 44-53. [CrossRef]

6. Stechauner-Rohringer, R. Redescripción de inmaduros, ciclo de vida, distribución e importancia agrícola de Cyclocephala lunulata Burmeister (Coleoptera: Melolonthidae: Dynastinae) en Colombia. Bol. Cient. Mus. Hist. Nat. 2010, 14, 203-220.

7. Dicke, M.; Sabelis, M.W. Infochemical terminology: Based on cost benefit analysis rather origin of compounds. Funct. Ecol. 1988, 2, 131-139. [CrossRef]

8. Mitchell-Olds, T.; Gershenzon, J.; Baldwin, I.; Boland, W. Chemical ecology in the molecular era. Trends Plant Sci. 1998, 3, 362-365. [CrossRef]

9. Robbins, P.S.; Crocker, R.L.; Nojima, S.; Morris, B.D.; Roelofs, W.L.; Villani, M.G. Methyl 2-(methylthio) benzoate: The unique sulfur-containing sex pheromone of Phyllophaga crinite. J. Insect Sci. 2003, 11, 517-520. [CrossRef]

10. Romero-López, A.A.; Arzuffi, R. Evidencias sobre la producción y liberación de compuestos bioactivos de la feromona sexual de un melolóntido mexicano. In Ecología y Control de Plagas Edafícolas; Rodríguez del Bosque, L.A., Morón, M.A., Eds.; Publicación especial del Instituto de Ecología AC: Xalapa, Mexico, 2010; Volume 1, pp. 204-222.

11. Leal, W.S. Chemical ecology of phytagous scarab beetles. Annu. Rev. Entomol. 1998, 43, 39-61. [CrossRef]

12. Facundo, H.T.; Linn Jr., C.E.; Villani, M.G.; Roelofs, W.L. Emergence, mating, and postmating behaviors of the Oriental beetle (Coleoptera: Scarabaeidae). J. Insect Behav. 1999, 12, 175-192. [CrossRef]

13. Benítez-Herrera, L.N.; Martínez, I.; Romero-López, A.A. Anatomía del aparato reproductor de Macrodactylus mexicanus (Coleoptera: Scarabaeoidea: Melolonthidae) y su posible participación en su comunicación química sexual. Southwest. Entomol. 2015, 40, 189-198. [CrossRef]

14. Romero-López, A.A.; Arzuffi, R.; Valdez, J.; Sánchez-Espíndola, E.; Morón, M.A. Tissues involved in sex pheromone production in Phyllophaga obsoleta (Coleoptera: Scarabaeoidea: Melolonthidae). Ann. Entomol. Soc. Am. 2011, 104, 960-965. [CrossRef]

15. Hoyt, C.P.; Osborne, G.O.; Mulcock, A.P. Production of an insect sex attractant by symbiotic bacteria. Nature 1971, 230, 472-473. [CrossRef] [PubMed]

16. Marshall, D.G.; Jackson, T.A.; Unelius, C.R.; Wee, S.L.; Young, S.D.; Townsend, R.J.; Suckling, D.M. Morganella morganii bacteria produces phenol as the sex pheromone of the New Zealand grass grub from tyrosine in the colleterial gland. Sci. Nat. 2016, 103, 59. [CrossRef]

17. Rosete-Enríquez, M.; Romero-López, A.A. Klebsiella bacteria isolated from the genital chamber of Phyllophaga obsoleta 1. Southwest. Entomol. 2017, 42, 1003-1013. [CrossRef]

18. Schulz, S.; Dickschat, J.S. Bacterial volatiles: The smell of small organisms. Nat. Prod. Rep. 2007, 24, 814-842. [CrossRef]

19. Kai, M.; Haustein, M.; Molina, F.; Petri, A.; Scholz, B.; Piechulla, B. Bacterial volatiles and their action potential. App. Microbiol. Biotechnol. 2009, 81, 1001-1012. [CrossRef]

20. Turton, L.J.; Drucker, D.B.; Ganguli, L.A. Effect of glucose concentration in the growth medium upon neutral and acidic fermentation end-products of Clostridium bifermentans, Clostridium sporogenes and Peptostreptococcus anaerobius. J. Med. Microbiol. 1983, 16, 61-67. [CrossRef]

21. Gao, C.; Wang, A.; Wu, W.M.; Yin, Y.; Zhao, Y.G. Enrichment of anodic biofilm inoculated with anaerobic or aerobic sludge in single chambered air-cathode microbial fuel cells. Bioresour. Technol. 2014, 167, 124-132. [CrossRef] 
22. Jia, B.; Sohnlein, B.; Mortelmans, K.; Coggiola, M.; Oser, H. Distinguishing Methicillin resistant and sensitive Staphylococcus aureus using volatile headspace metabolites. IEEE. Sens. J. 2010, 10, 71-75. [CrossRef]

23. Rowan, D.D. Volatile metabolites. Metabolites 2011, 1, 41-63. [CrossRef] [PubMed]

24. Tait, E.; Perry, J.D.; Stanforth, S.P.; Dean, J.R. Identification of volatile organic compounds produced by bacteria using HS-SPME-GC-MS. J. Chromatogr. Sci. 2014, 52, 363-373. [CrossRef] [PubMed]

25. Elgaali, H.; Hamilton-Kemp, T.R.; Newman, M.C.; Collins, R.W.; Yu, K.; Archbold, D.D. Comparison of long-chain alcohols and other volatile compounds emitted from food-borne and related Gram positive and Gram negative bacteria. J. Basic. Microbiol. 2002, 42, 373-380. [CrossRef]

26. Hamilton-Kemp, T.; Newman, M.; Collins, R.; Elgaali, H.; Yu, K.; Archbold, D. Production of the long-chain alcohols octanol, decanol, and dodecanol by Escherichia coli. Curr. Microbiol. 2005, 51, 82-86. [CrossRef]

27. Thibout, E.; Guillot, J.F.; Auger, J. Microorganisms are involved in the production of volatile kairomones affecting the host seeking behaviour of Diadromus pulchellus, a parasitoid of Acrolepiopsis assectella. Physiol. Entomol. 1993, 18, 176-182. [CrossRef]

28. Verhulst, N.O.; Beijleveld, H.; Knols, B.G.; Takken, W.; Schraa, G.; Bouwmeester, H.J.; Smallegange, R.C. Cultured skin microbiota attracts malaria mosquitoes. Malar. J. 2009, 8, 302. [CrossRef]

29. Zhu, J.J.; Chaudhury, M.F.; Durso, L.M.; Sagel, A.; Skoda, S.R.; Jelvez-Serra, N.S.; Santanab, E.G. Semiochemicals released from five bacteria identified from animal wounds infested by primary screwworms and their effects on fly behavioral activity. PLoS ONE 2017, 12, e0179090. [CrossRef]

30. Blomquist, G.J.; Figueroa-Teran, R.; Aw, M.; Song, M.; Gorzalski, A.; Abbott, N.L.; Tittiger, C. Pheromone production in bark beetles. Insect Biochem. Mol. 2010, 40, 699-712. [CrossRef]

31. Thacker, J.R.; Train, M.R. Use of volatiles in pest control. Chem. Biol. Volatiles 2010, 5, 151-172. [CrossRef]

32. Davis, T.S.; Crippen, T.L.; Hofstetter, R.W.; Tomberlin, J.K. Microbial Volatile Emissions as Insect Semiochemicals. J. Chem. Ecol. 2013, 30, 840-859. [CrossRef] [PubMed]

33. Robacker, D.C.; Lauzon, C.R.; He, X. Volatiles production and attractiveness to the Mexican fruit fly of Enterobacter agglomerans isolated from apple maggot and Mexican fruit flies. J. Chem. Ecol. 2004, 30, 1329-1347. [CrossRef] [PubMed]

34. Naaz, N.; Choudhary, J.S.; Prabhakar, C.S.; Moanaro; Maurya, S. Identification and evaluation of cultivable gut bacteria associated with peach fruit fly, Bactrocera zonata (Biptera: Tephritidae). Phytoparasitica 2016, 44, 165-176. [CrossRef]

35. Dillon, R.; Vennard,C.; Charnley, A. A Note: Gut bacteria produce components of a locust cohesion pheromone. J. Appl. Microbiol. 2002, 92, 759-763. [CrossRef]

36. Wada-Katsumata, A.; Zurek, L.; Nalyanya, G.; Roelofs, W.L.; Zhang, A.; Schal, C. Gut bacteria mediate aggregation in the German cockroach. Proc. Natl. Acad. Sci. USA 2015, 112, 15678-15683. [CrossRef]

37. Hallett, R.H.; Perez, A.L.; Gries, G.; Gries, R.; Pierce Jr, H.D.; Yue, J.; Oehlschlager, A.C.; Gonzalez, L.M.; Borden, J.H. Aggregation pheromone of coconut rhinoceros beetle, Oryctes rhinoceros (L.) (Coleoptera: Scarabaeidae). J. Chem. Ecol. 1995, 21, 1549-1570. [CrossRef]

38. Tolasch, T.; Solter, S.; Tóth, M.; Ruther, J.; Francke, W. (R)-acetoin-female sex pheromone of the summer chafer Amphimallon solstitiale (L.). J. Chem. Ecol. 2003, 29, 1045-1050. [CrossRef]

39. Rochat, D.; Ramirez Lucas, P.; Malosse, C.; Aldana, R.; Kakul, T.; Morin, J.P. Role of solid-phase microextraction in the identification of highly volatile pheromones of two Rhinoceros beetles Scapanes australis and Strategus aloeus (Coleoptera, Scarabaeidae, Dynastinae). J. Chromatogr. 2000, 885, 433-444. [CrossRef]

40. Oike, M.; Kanayama, S.; Wakamura, S. Mate-searching behavior of the black chafer Holotrichia kiotonensis (Coleoptera: Scarabaeidae): Identification of a sex pheromone, and male orientation behavior controlled by olfactory and visual cues. Appl. Entomol. Zool. 2017, 52, 519-526. [CrossRef]

41. Ruther, J.; Reinecke, A.; Hilker, M.; Tolasch, T. Phenol-another cockchafer attractant shared by Melolontha hippocastani fabr. and M. melolontha L. Z. Fur Naturforsch-Sect. C J. Biosci. 2002, 57, 910-913. [CrossRef]

42. Robacker, D.C.; Bartelt, R.J. Chemical attractive Mexican fruit fly from Klebsiella pneumoniae and Citrobacter freundii cultures sampled by solid-phase microextraction. J. Chem. Ecol. 1997, 23, 2897-2915. [CrossRef]

43. Alves, M.S.; da Silva Dias, R.C.; de Castro, A.C.D.; Riley, L.W.; Moreira, B.M. Identification of clinical isolates of indole-positive and indole-negative Klebsiella spp. J. Clin. Microbiol. 2006, 44, 3640-3646. [CrossRef] [PubMed] 
44. Lü, Z.X.; Song, W. Research of indole-3-acetic acid biosynthetic pathway of Klebsiella oxytoca SG-11 by HPLC and GC-MS. Sepu Chin. J. Chromatogr. 2000, 18, 328.

45. Xu, T.; Wang, C.; Zhu, S.; Zheng, G. Enzymatic preparation of optically pure t-butyl 6-chloro-(3R, 5S)-dihydroxyhexanoate by a novel alcohol dehydrogenase discovered from Klebsiella oxytoca. Process Biochem. 2017, 57, 72-79. [CrossRef]

46. Engel, E.; Baty, C.; LeCorre, D.; Souchon, I.; Martin, N. Flavor-active compounds potentially implicated in cooked cauliflower acceptance. J. Agric. Food Chem. 2002, 50, 6459-6467. [CrossRef]

47. Hayes, R.A.; Richardson, B.J.; Claus, S.C.; Wyllie, S.G. Semiochemicals and social signaling in the wild European rabbit in Australia: II. Variations in chemical composition of chin gland secretion across sampling sites. J. Chem. Ecol. 2002, 28, 2613-2625. [CrossRef]

48. Ong, P.K.C.; Acree, T.E. Similarities in the aroma chemistry of Gewürztraminer variety wines and Lychee (Litchi chinesis Sonn.) fruit. J. Agric. Food Chem. 1999, 47, 665-670. [CrossRef]

49. Farkas, O.; Heberger, K. Comparison of ridge regression, partial least-squares, pairwise correlation, forward and best subset selection methods for prediction of retention indices for aliphatic alcohols. J. Chem. Inf. Model. 2005, 45, 339-346. [CrossRef]

50. Adams, R.P. Identification of Essential Oil Components by Gas Chromatography/Mass Spectrometry; Allured Publishing Corporation: Carol Stream, IL, USA, 1995.

51. Bendimerad, N.; Bendiab, S.A.T.; Benabadji, A.B.; Fernandez, X.; Valette, L.; Lizzani-Cuvelier, L. Composition and antibacterial activity of Pseudocytisus integrifolius (Salisb.) essential oil from Algeria. J. Agric. Food Chem. 2005, 53, 2947-2952. [CrossRef]

52. Aznar, M.; Lopez, R.; Cacho, J.; Ferreira, V. Identification and quantification of impact odorants of aged red wines from Rioja. GC-olfactometry, quantitative GC-MS, and odor evaluation of HPLC fractions. J. Agric. Food Chem. 2001, 49, 2924-2929. [CrossRef]

53. De Marques, F.A.; McElfresh, J.S.; Millar, J.G. Kováts retention indexes of monounsaturated C12, C14, and $\mathrm{C} 16$ alcohols, acetates and aldehydes commonly found in lepidopteran pheromone blends. J. Braz. Chem. Soc. 2000, 11, 592-599. [CrossRef]

54. Tellez, M.R.; Schrader, K.K.; Kobaisy, M. Volatile components of the cyanobacterium Oscillatoria perornata (Skuja). J. Agric. Food Chem. 2001, 49, 5989-5992. [CrossRef] [PubMed]

55. Kim, B.; Cho, B.R.; Hahn, J.S. Metabolic engineering of Saccharomyces cerevisiae for the production of 2-phenylethanol via Ehrlich pathway. Biotechnol. Bioeng. 2014, 111, 115-124. [CrossRef] [PubMed]

56. Henzell, R.F.; Lowe, M.D. Sex attractant of the grass grub beetle. Science 1970, 168, 1005-1010. [CrossRef]

57. Harrison, R.A. Grass grub attractant identified. N. Z. J. Agric. Res. 1970, 121, 25.

58. Zarbin, P.H.G.; Leal, W.S.; Ávila, C.J.; Oliveira, L.J. Identification of the sex pheromone of Phyllophaga cuyabana (Coleoptera: Melolonthidae). Tetrahedron Lett. 2007, 48, 1991-1992. [CrossRef]

59. Gruner, L.; Marival, D. The attraction of males of the West Indian beetle Cyclocephala insulicola Arrow by phenol (Coleoptera: Dynastinae). C.R. Acad. Seances Agric. Fr. 1974, 60, $203-208$.

60. Zhang, A.; Robbins, S.A.; Leal, W.S.; Lin, C., Jr.; Villani, M.G.; Roelofs, W.L. Essential amino acid methyl esters: Major sex pheromone components of the cranberry white grub, Phyllophaga anxia (Coleoptera: Scarabaeidae). J. Chem. Ecol. 1997, 23, 231-245. [CrossRef]

61. Yasui, H.; Wakamura, S.; Tanaka, S.; Harano, K.; Mochizuki, F.; Nagayama, A.; Hokama, Y.; Arakaki, N. Quantification of 2-butanol as a sex attractant pheromone and related alcohols emitted by individual white grub beetle, Dasylepida ishigakiensis (Coleoptera: Scarabaeidae). App. Entomol. Zool. 2010, 45, 129-135. [CrossRef]

62. Ju, Q.; Guo, X.; Li, X.; Jiang, X.; Jiang, X.; Ni, W.; Qu, M. Plant volatiles increase sex pheromone attraction of Holotrichia parallela (Coleoptera: Scarabaeoidea). J. Chem. Ecol. 2017, 43, 236-242. [CrossRef]

63. Cardé, R.T. Defining attraction and aggregation pheromones: Teleological versus functional perspectives. J. Chem. Ecol. 2014, 40, 519-520. [CrossRef] [PubMed]

64. Toffin, E.; Gabriel, E.; Louis, M.; Deneubourg, J.; Grégoire, J. Colonization of weakened trees by mass-attacking bark beetles: No penalty for pioneers, scattered initial distributions and final regular patterns. R. Soc. Open Sci. 2018, 5, 170454. [CrossRef] [PubMed]

65. Gries, G.; Gries, R.; Perez, A.L.; Oehlschlager, A.C.; Gonzales, L.M.; Pierce, H.D.; Zebeyou, M.; Kouame, B.; Kouame, B. Aggregation pheromone of the african rhinoceros beetle, Oryctes monoceros (Olivier) (Coleoptera: 
Scarabaeidae) b-binding site of photosystem ii. Z. Fur Naturforsch.-Sect. C J. Biosci. 1994, 49, 363-366. [CrossRef]

66. Morin, J.P.; Rochat, D.; Malosse, C.; Lettere, M.; De Chenon, R.D.; Wibwo, H.; Descoins, C. Ethyl 4-methyloctanoate, major component of Oryctes rhinoceros (L.) (Coleoptera, Dynastidae) male pheromone. C.R. Acad. Sci. Paris. 1996, 319, 595-602. [PubMed]

67. Rochat, D.; Mohammadpoor, K.; Malosse, C.; Avand-Faghih, A.; Lettere, M.; Beauhaire, J.; Morin, J.P.; Pezier, A.; Renou, M.; Abdollahi, G.A. Male aggregation pheromone of date palm fruit stalk borer Oryctes elegans. J. Chem. Ecol. 2004, 30, 387-407. [CrossRef] [PubMed]

68. Allou, K.; Morin, J.P.; Kouassi, P.; N'klo, F.H.; Rochat, D. Oryctes monoceros trapping with synthetic pheromone and palm material in Ivory coast. J. Chem. Ecol. 2006, 32, 1743-1754. [CrossRef]

69. Said, I.; Hasni, N.; Abdallah, Z.; Couzi, P.; Ouhichi, M.; Renou, M.; Rochat, D. Identification of the aggregation pheromone of the date palm root borer Oryctes agamemnon. J. Chem. Ecol. 2015, 41, 446-457. [CrossRef] [PubMed]

70. Leal, W.S.; Yadava, C.P.S.; Vijayvergia, J.N. Aggregation of the scarab beetle Holotrichia consanguinea in response to female-released pheromone suggests secondary function hypothesis for semiochemical. J. Chem. Ecol. 1996, 22, 1557-1566. [CrossRef]

71. Arakaki, N.; Wakamura, S.; Yasui, H.; Sadoyama, Y.; Kishita, M. Sexually differentiated functions of female-produced pheromone of the black chafer Holotrichia loochooana loochooana (Sawada) (Coleoptera: Scarabaeidae). Chemoecology 2003, 13, 183-186. [CrossRef]

72. Hunt, D.W.A.; Borden, J.H. Conversion of verbenols to verbenone by yeasts isolated from Dendroctonus ponderosae (Coleoptera: Scolytidae). J. Chem. Ecol. 1990, 16, 1385-1397. [CrossRef]

73. Kubo, I.; Muroi, H.; Kubo, A. Structural functions of antimicrobial long-chain alcohols and phenols. Bioorg. Med. Chem. 1995, 3, 873-880. [CrossRef]

74. Ruiu, L. Insect Pathogenic Bacteria in Integrated Pest Management. Insects 2015, 6, 352-367. [CrossRef]

75. Morón, M.A.; Ratcliffe, B.C.; Deloya, C. Atlas de los Escarabajos de México. Coleoptera: Lamellicornia. Vol. I. Familia Melolonthidae; Publicación especial de la Sociedad Mexicana de Entomología, A.C. y Conabio: México, Mexico, 1997.

76. Hall, T.A. BioEdit: A user-friendly biological sequence alignment editor and analysis program for Windows 95/98/NT. Nucleic Acids Symp. Ser. 1999, 41, 95-98.

77. Thompson, J.D.; Higgins, D.G.; Gibson, T.J. CLUSTAL W: Improving the sensitivity of progressive multiple sequence alignment through sequence weighting, position-specific gap penalties and weight matrix choice. Nucleic Acids Res. 1994, 22, 4673-4680. [CrossRef] [PubMed]

78. Saitou, N.; Nei, M. The neighbor-joining method: A new method for reconstructing phylogenetic trees. Mol. Biol. Evol. 1987, 4, 406-425. [CrossRef] [PubMed]

79. Kimura, M. A simple method for estimating evolutionary rate of base substitutions through comparative studies of nucleotide sequences. J. Mol. Evol. 1980, 16, 111-120. [CrossRef] [PubMed]

80. Kumar, S.; Stecher, G.; Tamura, K. MEGA7: Molecular Evolutionary Genetics Analysis Version 7.0 for Bigger Datasets. Mol. Biol. Evol. 2017, 33, 1870-1874. [CrossRef] [PubMed]

81. Clarke, E.G. Isolation and identification of drugs. Pharm. Press 1978, 2, 927-928.

Sample Availability: Samples are not available from the authors. 